\title{
$\begin{array}{ll}\text { Research Square } & \text { Preprints are preliminary reports that have not undergone peer review. } \\ \text { They should not be considered conclusive, used to inform clinical practice, }\end{array}$
}

\section{Obesity is potentially associated with a novel mitochondrial tRNAGly $10029 A>G$ mutation in a Chinese family}

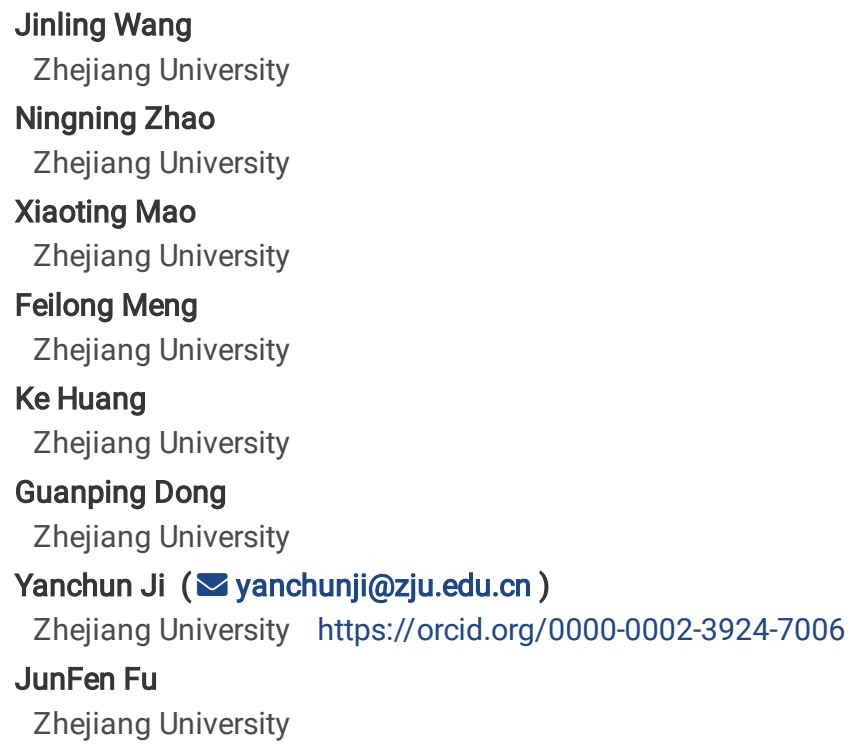

Research article

Keywords: Children, Chinese,Obesity, Mitochondrial tRNA, Mutation

Posted Date: August 21st, 2019

DOI: https://doi.org/10.21203/rs.2.13325/v1

License: (c) (i) This work is licensed under a Creative Commons Attribution 4.0 International License. Read Full License 


\section{Abstract}

Background Obesity is one of the most prominent public health challenges globally. Mutations in mitochondrial genes can similarly lead to the onset of childhood obesity remains unclear. Methods we conducted a clinical, genetic, and molecular profiling of a Han Chinese family with evident of matrilineally-inherited obesity. Obesity was evident in 2/6 matrilineal relatives in a single generation of this family (of 3 available generations). When the mitochondrial DNA of these individuals was sequences and a pedigree analysis was performed. Results We were able to identify a novel homoplasmic mutation of the mitochondrial tRNAGly gene $(10029 \mathrm{~A}>\mathrm{G})$ in these individuals. This mutation was linked to destabilization of a conserved base pair in the anticodon of this tRNA. This position (position 43) is known to be important for mediating effective codon recognition and tRNA stability. Consistent with the importance of this conserved site, we found that the predicted structure of a tRNAGly structure bearing a 10029A $>$ G mutation was markedly altered in a molecular dynamics simulation relative to the wild-type isoform. All other mutations identified in the mtDNA of this individual were known variants associated with Asian haplogroup D4. Conclusion Our report provides novel evidence of a link between a tRNA mutation and an elevated risk of maternally-transmissible obesity risk, offering potentially novel insights into the underlying nature of obesity.

\section{Background}

Obesity is one of the most prominent public health challenges globally, with an over 10-fold increase in the number of obese children over the last 40 years [1, 2]. The exact causes of obesity are not fully understood, and are multifactorial in nature [3]. Childhood obesity can often be complicated by underlying type 2 diabetes, cardiovascular disease, hypertension, or abnormal puberty [3, 4]. Mutations in single genes can mediate obesity, or it can arise from the complex interactions between environmental and genetic factors. To date, research efforts aimed at detecting mutations linked to obesity have primarily focused on nuclear genes, with mutations in MC4R, BDNF FTO, and PCKS1 having previously been detected via genome-wide association studies [5]. Whether mutations in mitochondrial genes can similarly lead to the onset of childhood obesity, however, remains unclear. Studies have recently found that mutations in mtDNA are linked to obesity, and specifically many mutations in the mitochondrial tRNA genes have been shown to be associated with metabolic disorders and diabetes. For example, the m.10003T $>C$ mutation in tRNA ${ }^{\text {Gly }}$, as well as the m.14692A $>\mathrm{G}$ and m.14709T>C mutations in tRNA ${ }^{\text {Glu }}$ have been linked to such disease [6-8].

It is highly likely that, given their association with other metabolic disorders, mitochondrial tRNA mutations have the potential to be linked to an increased risk of childhood obesity. We therefore sought to systematically sequence the mitochondrial g genomes of obese Chinese children in an effort to detect deleterious mutations. To identify mutations likely to have a significant association with obesity, we focused specifically on those which were present in $<1 \%$ of non-obese controls, evolutionarily conserved in 17 other vertebrate species, and present with established tRNA secondary structural elements such as hairpins, loops, the stem region, or anticodon loops, as mutations in such structures would be more likely to alter tRNA stability or codon-anticodon interactions so as to impact translational activity [9, 10]. We also relied upon mtDNA haplogroup nomenclature to assign the identified mtDNAs of studies subjects to specific Asian mtDNA haplogroups [11].

\section{Methods}

\section{Subjects}

We recruited an obese 10.5 year-old Han Chinese boy who had presented in our endocrinology department with complaints of weight gain over the previous 3 year period. For the purposes of this study, a BMI greater than the $95^{\text {th }}$ percentile of age- and sex-matched individuals, while severe obesity was present if this was $>99^{\text {th }}$ percentile as defined by the Chinese Working Group on Obesity and the CDC in 2010 [12, 13 ]. This study was conducted in a manner consistent with the Declaration of Helsinki. All participating family members provided informed consent, in addition to donating blood samples and undergoing a full clinical assessment. The Ethic Committees of the Children's Hospital, Zhejiang University School of Medicine approved all aspects of this study. For each participant in this study, a medical history interview was taken to determine whether there was any family history of obesity or other diseases. As controls, 100 children in the same region were recruited to assess for the presence of these same mtDNA mutations.

\section{Clinical examinations}

The subject of interest underwent a complete physical wherein their height and weight were determined to within $0.5 \mathrm{~cm}$ and $0.1 \mathrm{~kg}$, respectively. These values were then used in order to calculate BMI based on the formula BMI = weight $(\mathrm{kg}) /$ height $(\mathrm{m})^{2}$. Blood pressure was measured twice for the participant, with the average reading recorded and with measurements made while the subject remained in a seated quite position.

In addition to the physical examination, a routine metabolic workup was used to assess Alanine aminotransferase (ALT), aspartate aminotransferase (AST), fasting triglycerides, total cholesterol, high-density lipoprotein (HDL), and low-density lipoprotein (LDL) levels in this participant. In addition, an oral glucose tolerance test was performed and glucose as well as insulin levels were measured. In addition, the participant underwent a Liver B-Ultrasound (BUS) examination with a convex 3.5-5.0 MHz probe (GE, LOGIC 500). 
Whole genomic DNA was extracted with the Puregene DNA Isolation Kit (Qiagen), after which the entirety of the mitochondrial genome was amplified via PCR in 99 separate fragments, which were amplified using primers for heavy and light stranded DNA in a total of three pooled reactions. After PCR amplification, magnetic beds were used to purify the DNA and a library was prepared for direct sequencing using a MiniSeq sequencer with a next-generation sequencing reaction kit (Illumina). The consensus Cambridge sequence (GenBank accession number: NC_012920) was then used as a reference for identifying mutations within the obtained genome [14].

The following PCR primers were used for identification of the m.10029A $>$ G mutation in the mitochondrial tRNA ${ }^{\text {Gly }}$ gene, amplifying the 9211 10149 region: F:5'-CCC ACC AAT CAC ATG CCT AT-3' and R:5'-TGT AGC CGT TGA GTT GTG GT-3', as reported previously [14]. Isolated fragments were then analyzed as in previous studies [15].

\section{Haplogroup Analyses}

Asian mitochondrial haplogroups were identified in accordance with the mitochondrial haplogroup nomenclature conventions with the help of an online tool (http://www.mitotool.org/ genomeRSRS.html).[11,16]

\section{Structural Analysis and Molecular Dynamics Simulations}

tRNA secondary structural elements were identified based on previously published secondary structures [17].

The Sus scrofa mitochondrial tRNA (Protein Data Bank entry 5AJ3) was used as a reference to identify the coordinates corresponding to the wild-type tRNA ${ }^{\text {Gly }}$ anticodon stem and loop (ASL). The Chimera program was used to substitute nucleoside bases per the mitochondrial tRNA ${ }^{\text {Gly }}$ sequence [18]. The A30C mutation coordinates were similarly generated based on the wild-type tRNA Gly using Chimera. As a solvent, $50 \mathrm{mM}$ $\mathrm{NaCl}$ was added in addition to $\mathrm{Na}^{+}$or $\mathrm{Cl}^{-}$neutralization, yielded a wild-type ASL system composed of 8996 atoms and a mutant system composed of 9015 atoms.

The Amber14 program was used to conduct molecular dynamics (MD) simulations [19]. MD trajectories were propagated every 0.02 fs via a shaking algorithm for each hydrogen with a non-bonded cut off [20]. Unfavorable contacts were relieved through energy minimization, as well as by solvent equilibration, equilibrating at $300 \mathrm{~K}$ and 1 bar in the NPT ensemble with a periodic boundary condition. Positional restraints were initially imposed on the all ALS atoms for 500PS. Following equilibration, production simulations were conducted with time intervals of 2 fs for up to $100 \mathrm{~ns}$ in total.

\section{Phylogenetic Analysis}

Mitochondrial tRNA sequences from 17 vertebrate species were utilized to conduct an interspecific analysis, as in previous reports [21]. A conservation index $(\mathrm{Cl})$ value was determined via comparing nucleotides in the human tRNA gene with those in the other 16 vertebrate species, with $\mathrm{Cl}$ being determined to be the percentage of the assessed species with the human wild-type nucleotide present at the indicated position.

\section{Statistics Analysis}

SPSS v17.0 was used for all statistical testing, with $P<0.05$ as the significance threshold. Fisher's exact test was used to compare frequencies of tRNA mutations between obese and control children.

\section{Results}

\section{Case Presentation}

As shown in Figure 1, the proband subject in this analysis was a Han Chinese boy who was 10.5 years of age and who had presented with marked weight gain over the preceding three years, with no other reported prior health issues. Upon physical examination, the boy was found to have $46.2 \%$ body fat, as well as thick and dark skin in the armpits and neck (Table 1 ). The subject was $146.5 \mathrm{~cm}$ tall and weighed $56.0 \mathrm{~kg}$, for a total BMI of $26.1 \mathrm{Kg} / \mathrm{m}^{2}$. The participant had a waist-hip ratio of 0.9 and blood pressure of $135 / 76 \mathrm{mmHg}$, indicating the presence of hypertension. The subject was pre-pubescent, having a $3 \mathrm{~mL}$ testicular volume and a $4 \mathrm{~cm}$ penis length based upon Tanner Staging, with stage B3 breast development. The subject had an obese father (BMI $\left.30.2 \mathrm{Kg} / \mathrm{m}^{2}\right)$ and an overweight mother (BMI $\left.26.3 \mathrm{Kg} / \mathrm{m}^{2}\right)$. Family members were interviewed to determine their family history of obesity and other clinical abnormalities.

The subject had normal oral glucose tolerance, and a 5.9\% HbA1c result. According to BUS criteria the subject met the criteria for a NAFLD diagnosis, although liver function appeared normal (ALT $7 \mathrm{U} / \mathrm{L}$ and AST $22 \mathrm{U} / \mathrm{L}$ ). Lipid profile results were normal and as follows: triglycerides $0.97 \mathrm{mmol} /$ I囚cholesterol $5.34 \mathrm{mmol} / \mathrm{I}, \mathrm{HDL} 1.22 \mathrm{mmol} /$ I $\mathrm{LDL} 2.93 \mathrm{mmol} / \mathrm{I}$, Non-HDL $4.12 \mathrm{mmol} / \mathrm{L}$. The subject had no evidence of hyperuricemia. 
We sought to explore whether there was a genetic basis for the obesity of this study subject, leading us to sequence his entire mitochondrial genome. Upon comparison of this sequence with the Cambridge consensus sequence, we detected a total of 34 point mutations which coincided with the Eastern Asian haplogroup D4 (Table 2). Among these mutations, 7 were known mutations of the D-loop region, 2 were known 12S rRNA mutations, 2 were known 16S rRNA mutations, and a novel homoplasmic m.10029A>G mutation was also detected affecting the tRNA ${ }^{\text {Gly }}$ gene (Figure 2). The remaining mutations included 15 known to be silent, and 7 known to be missense in protein coding regions which were as follows: $m .8414 \mathrm{C}>\mathrm{T}$ (Leu17Phe) affecting ATP8, m.8701A>G (Thr59Ala) and m.8860A>G(Thr112Ala) affecting ATP6 gene, m. 9856T >C(Ile217Thr) affecting C03, the m.10398A>G(Thr114Ala) affecting ND3 gene, and m.14766C>T(Thr>lle) and m.15326A>G(Thr194Ala) affecting CYB. We next performed a phylogenetic comparison to assess how well these different mutated sites were conserved in humans relative to 16 other primate species, revealing a $100 \% \mathrm{Cl}$ value for the $\mathrm{RNA}^{\mathrm{Gly}} \mathrm{m} .10029 \mathrm{~A}>\mathrm{G}$ mutation, without clear evolutionary conservation for other identified mutations (Table 3). We also determined that this proband subject (HZF002) belonged to the Eastern Asian halpogroup D4 based on standard haplogroup designation nomenclature.

\section{Molecular dynamics simulation}

As the A42 site was found to be highly evolutionarily conserved (Figure 3 and Table 3), it is likely important to the overall structural integrity of tRNA ${ }^{\text {Gly }}$, consistent with its observed localization in the anticodon stem region. To confirm this structural importance, we conducted a molecular dynamics (MD) simulation assessing how this m.10029A $>$ G mutation might alter the tRNA ${ }^{\text {Gly }}$ structure, as this simulated approach has previously been validated as a means of assessing how disease-associated mutations affect protein structure [22,23]. As shown in Figure 4A, there was a more substantial variation in the root mean square deviation (RMSD) curve for the wild-type anticodon stem region isoform over the simulation period as compared to the mutated isoform, suggesting that this mutation has a structural impact on this tRNA ASL region. We further performed a root mean square fluctuation (RMSF) assessment to explore how this mutation affected tRNA ASL region mobility, revealing that the mutated isoform was less flexible than was the wild-type isoform, consisting with an adverse impact of this mutation on $42 \mathrm{G}-28 \mathrm{U}$ basepairing and consequent tRNA ${ }^{\text {Gly }}$ structural stability (Figure 4B).

\section{Discussion}

Herein, we analyzed the genetic, clinical, and molecular findings from a Han Chinese family with evidence of obesity, with matrilineal relatives in this family being obese across three generations, with obesity manifesting at a range of ages and beginning at age 7 in the proband patient. As this obesity appeared to be transmitted in a matrilineal manner, this suggested a possible mtDNA mutation as the underlying cause. We therefore sequenced the mtDNA of the proband subject, detecting 34 mutations consistent with the Eastern Asian haplogroup D4 [11, 12], of which 33 were not evolutionarily conserved and are thus unlikely to be linked to disease. The remaining homoplasmic $\mathrm{m}$. 10029A $>\mathrm{G}$ mutation, however, affected a nucleotide (A42) with a high degree of evolutionary conservation and which is present within the tRNA Gly anticodon stem wherein it is important for maintaining tRNA stability (21). The base-paring destabilization predicted to occur as a result of this mutation is likely to alter the tRNA structure, as previously documented for other mutations including tRNA ${ }^{\text {Thr }} 15927 G>A$, tRNA ${ }^{\text {lle }} 4300 A>G$, and tRNA ${ }^{\text {Leu(UUR) }}$ $3273 T>C(22,24,25)$. An MD simulation confirmed this hypothesis, revealing that the m.10029A $>G$ mutation altered tRNA secondary structural stability and mobility. Furthermore, the m.10029A $>$ G mutation perturbed the conformation of tRNA ${ }^{\text {Gly }}$, similar with the faster electrophoretic mobility of mutated tRNAs carrying the m.4435A>G, m.3253T>C and m.15927A>G mutations [22,26,27].

This is the first report of a novel mitochondrial tRNA mutation with the potential to be linked to childhood obesity in a Chinese population. Our results and MD simulation findings suggest that the m.10029A>G mutation may have relevance as a possible inherited risk factor linked to the diagnosis of obesity, and these data thus give new insights into the underlying molecular mechanisms of maternally transmissible obesity risk, suggesting possible avenues for future treatment. Further studies will be needed to definitively assess how mitochondrial dysfunction is linked to the onset of obesity in vivo, in order to better understand how to manage genetic obesity risk in the global population.

\section{Abbreviations}

BMl: body mass index

CDC: centers for disease control

HDL: high density lipoprotein

LDL: low density lipoprotein

PCR: polymerase chain reaction 
MD: molecular dynamics

NAFLD: non-alcoholic fatty liver disease

RMSD: root mean square deviation

\section{Declarations}

\section{Ethics approval and consent to participate}

All subjects were willing to participate in the study and the written informed consent for clinical evaluations and genetic analysis were obtained from each participant. In addition, the protocol of the study was approved by the medical ethics committee of the Children's Hospital, Zhejiang University School of Medicine. Written informed consent was obtained from all adult subjects and parents of minor subjects.

\section{Consent for publication}

Written informed consent to publish this information was obtained from study participants. All the data are available for the consultation.

\section{Availability of data and material}

Not applicable.

\section{Competing interests}

The authors declare that they have no competing interests.

\section{Funding}

Funded by National Key R\&D Program of China (2016YFC1305300) to JF ; National Natural Science Foundation of China (81570757) to JF; Jin Lei Pediatric Endocrinology Growth Research Fund for Young Physicians (PEGRF) (No. PEGRF 201809002) to JW.

\section{Authors' contributions}

YJ and JF designed the experiments. JW, NZ, KH and GD collected the blood samples and extracted DNA from the blood samples. JW, XM and FM analyzed the raw data. JW, JF and YJ wrote the manuscript. YJ and JF participate in revising the manuscript. All authors read and approved the final manuscript.

\section{Acknowledgements}

Not applicable.

\section{References}

[1].Peng S, Zhu Y, Xu F, Ren X, Li X, Lai M. FTO gene polymorphisms and obesity risk: a meta-analysis. BMC Med. $2011 ; 9: 71$.

[2].Cole TJ, Bellizzi MC, Flegal KM, Dietz WH. Establishing a standard definition for child overweight and obesity worldwide: international survey. BMJ. 2000;320(7244):1240-3.

[3]. Van der Klaauw AA, Farooqi IS. The hunger genes: pathways to obesity. Cell. 2015;161(1):119-32.

[4]. Dai YL, Fu JF, Liang L, Gong CX, Xiong F, Luo FH, Liu GL, Chen SK. Association between obesity and sexual maturation in Chinese children: a muticenter study. Int J Obes. 2014; 38(10):1312-1316

[5]. Pigeyre M, Yazdi FT, Kaur Y, Meyre D. Recent progress in genetics, epigenetics and metagenomics unveils the pathophysiology of human obesity. Clinical Science. 2016;130(12):943-86.

[6]. Liu H, Li R, Li W, Wang M, Ji J, Zheng J, Mao Z, Mo JQ, Jiang P, Lu J, Guan MX. Maternally inherited diabetes is associated with a homoplasmic T10003C mutation in the mitochondrial tRNA(Gly) gene. Mitochondrion. 2015; 21:49-57.

[7]. Mezghani N, Mkaouar-Rebai E, Mnif M, Charfı N, Rekik N, Youssef S, Abid M, Fakhfakh F. The heteroplasmic m.14709T>C mutation in the tRNA(Glu) gene in two Tunisian families with mitochondrial diabetes. J Diabetes Complications. 2010; 24(4):270-7. 
[8]. Wang M, Liu H, Zheng J, Chen B, Zhou M, Fan W, Wang H, Liang X, Zhou X, Eriani G, Jiang P, Guan MX. A deafness- and diabetes-associated tRNA mutation causes deficient pseudouridinylation at position 55 in tRNA ${ }^{\text {Glu }}$ and mitochondrial dysfunction. J Biol Chem. 2016;291(40):2102921041.

[9]. Xue L, Wang M, Li H, Wang H, Jiang F, Hou L, Geng J, Lin Z, Peng Y, Zhou H, Yu H, Jiang P, Mo JQ, Guan MX. Mitochondrial tRNA mutations in 2070 Chinese Han subjects with hypertension. Mitochondrion. 2016;30:208-21.

[10].Zheng J, Ji Y, Guan MX. Mitochondrial tRNA mutations associated with deafness. Mitochondrion. 2012;12(3):406-13.

[11].Kong QP, Bandelt HJ, Sun C, Yao YG, Salas A, Achilli A, Wang CY, Zhong L, Zhu CL, Wu SF, Torroni A, Zhang YP. Updating the East Asian mtDNA phylogeny: a prerequisite for the identification of pathogenic mutations. Hum Mol Genet. 2006;15(13):2076-86.

[12]. WHO (2000) Obesity: Preventing and managing the global epidemic. Report on a WHO Consultation. Technical Report Series. Geneva. WHO. 2000; 894: 83

[13].Body mass index reference norm for screening overweight and obesity in Chinese children and adolescents. Group of China Obesity Task Force Chin J Epidemiol. 2004;25(2): 97-102

[14]. Andrews RM, Kubacka I, Chinnery PF, Lightowlers RN, Turnbull DM, Howell N. Reanalysis and revision of the Cambridge reference sequence for human mitochondrial DNA.Nat Genet. 1999;23(2):147.

[15]. Qin Y, Xue L, Jiang P, Xu M, He Y, Shi S, Huang Y, He J, Mo JQ, Guan MX. Mitochondrial tRNA variants in Chinese subjects with coronary heart disease. J Am Heart Assoc. 2014;3(1):e000437.

[16]. Tanaka M, Cabrera VM, González AM, Larruga JM, Takeyasu T, Fuku N, Guo LJ, Hirose R, Fujita Y, Kurata M, Shinoda K, Umetsu K, Yamada Y, Oshida Y, Sato Y, Hattori N, Mizuno Y, Arai Y, Hirose N, Ohta S, Ogawa O, Tanaka Y, Kawamori R, Shamoto-Nagai M, Maruyama W, Shimokata H, Suzuki R, Shimodaira H. Mitochondrial genome variation in eastern Asia and the peopling of Japan. Genome Res. 2004;14(10A):1832-50.

[17].Florentz C, Sohm B, Tryoen-Tóth P, Pütz J, Sissler M. Human mitochondrial tRNAs in health and disease. Cell Mol Life Sci. 2003;60(7):135675.

[18].Pettersen EF, Goddard TD, Huang CC, Couch GS, Greenblatt DM, Meng EC, Ferrin TE. UCSF Chimera-a visualization system for exploratory research and analysis. J Comput Chem. 2004;25(13):1605-12.

[19].Case DA, Cheatham TE 3rd, Darden T, Gohlke H, Luo R, Merz KM Jr, Onufriev A, Simmerling C, Wang B, Woods RJ. The Amber biomolecular simulation programs. J Comput Chem. 2005;26(16):1668-88.

[20].Kondratyuk ND, Norman GE, Stegailov VV. Self-consistent molecular dynamics calculation of diffusion in higher n-alkanes.J Chem Phys. 2016;145(20):204504.

[21].Pütz J, Dupuis B, Sissler M, Florentz C. Mamit-tRNA, a database of mammalian mitochondrial tRNA primary and secondary structures. RNA. 2007;13(8):1184-90.

[22].Jia Z, Zhang Y, Li Q, Ye Z, Liu Y, Fu C, Cang X, Wang M, Guan MX. A coronary artery disease-associated tRNA ${ }^{\text {Thr }}$ mutation altered mitochondrial function, apoptosis and angiogenesis. Nucleic Acids Res. 2019;47(4):2056-2074.

[23].Meng F, Cang X, Peng Y, Li R, Zhang Z, Li F, Fan Q, Guan AS, Fischel-Ghosian N, Zhao X, Guan MX. Biochemical Evidence for a Nuclear Modifier Allele (A10S) in TRMU (Methylaminomethyl-2-thiouridylate-methyltransferase) Related to Mitochondrial tRNA Modification in the Phenotypic Manifestation of Deafness-associated 12S rRNA Mutation. J Biol Chem. 2017;292(7):2881-2892.

[24]. Taylor RW, Giordano C, Davidson MM, d'Amati G, Bain H, Hayes CM, Leonard H, Barron MJ, Casali C, Santorelli FM, Hirano M, Lightowlers RN, DiMauro S, Turnbull DM. A homoplasmic mitochondrial transfer ribonucleic acid mutation as a cause of maternally inherited hypertrophic cardiomyopathy.J Am Coll Cardiol. 2003;41(10):1786-96.

[25]. Campos Y1, Gámez J, García A, Andreu AL, Rubio JC, Martín MA, del Hoyo P, Navarro C, Cervera C, Garesse R, Arenas J. A new mtDNA mutation in the tRNA(Leu(UUR)) gene associated with ocular myopathy.Neuromuscul Disord. 2001;11(5):477-80.

[26].Liu Y, Li R, Li Z, Wang XJ, Yang L, Wang S, Guan MX. Mitochondrial transfer RNAMet 4435A>G mutation is associated with maternally inherited hypertension in a Chinese pedigree. Hypertension. 2009;53(6):1083-90. 
[27].Zhou M, Wang M, Xue L, Lin Z, He Q, Shi W, Chen Y, Jin X, Li H, Jiang P, Guan MX. hypertension-associated mitochondrial DNA mutation alters the tertiary interaction and function of tRNA ${ }^{\text {Leu(UUR) }}$. J Biol Chem. 2017;292(34):13934-13946

\section{Tables}

Table 1 Summary of the obese individuals in a Chinese family

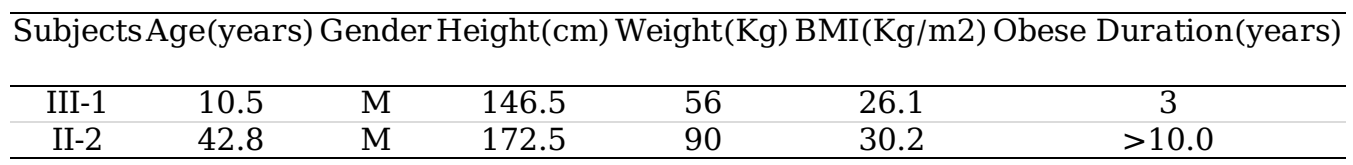

Table 2. mtDNA variants in a Chinese family with obesity.

\begin{tabular}{|c|c|c|c|c|}
\hline \multirow{2}{*}{$\begin{array}{l}\text { Gene } \\
\text {-loop }\end{array}$} & Position Replacement & \multicolumn{3}{|c|}{ Conservation No. of 300 Control subjects CRS HZF001 Previously reported } \\
\hline & $73 \mathrm{~A}-\mathrm{G}$ & $\mathrm{A}$ & $\mathrm{G}$ & Yes \\
\hline & $263 \mathrm{~A}-\mathrm{G}$ & A & G & Yes \\
\hline & $310 \mathrm{C}-\mathrm{CC}$ & $\mathrm{C}$ & $\mathrm{CC}$ & Yes \\
\hline & $489 \mathrm{~T}-\mathrm{C}$ & $\mathrm{T}$ & $\mathrm{C}$ & Yes \\
\hline & $16223 \mathrm{C}-\mathrm{T}$ & $\mathrm{C}$ & $\mathrm{T}$ & Yes \\
\hline & $16316 \mathrm{~A}-\mathrm{G}$ & $\mathrm{A}$ & $\mathrm{G}$ & Yes \\
\hline & $16362 \mathrm{~T}-\mathrm{C}$ & $\mathrm{T}$ & $\mathrm{C}$ & Yes \\
\hline$M T-R N R 1$ & $750 \mathrm{~A}-\mathrm{G}$ & $\mathrm{A}$ & $\mathrm{G}$ & Yes \\
\hline & $1438 \mathrm{~A}-\mathrm{G}$ & A & $\mathrm{G}$ & Yes \\
\hline$M T-R N R 2$ & $2706 \mathrm{~A}-\mathrm{G}$ & A & $\mathrm{G}$ & Yes \\
\hline & 3010 G-A & $\mathrm{G}$ & $\mathrm{A}$ & Yes \\
\hline$M T-N D 1$ & $3705 \mathrm{G}-\mathrm{A}$ & $\mathrm{G}$ & $\mathrm{A}$ & Yes \\
\hline$M T-N D 2$ & 4769A-G & A & $\mathrm{G}$ & Yes \\
\hline & $4883 \mathrm{C}-\mathrm{T}$ & $\mathrm{C}$ & $\mathrm{T}$ & Yes \\
\hline & $5178 \mathrm{C}-\mathrm{A}$ & $\mathrm{C}$ & $\mathrm{A}$ & Yes \\
\hline$M T-C O X 1$ & 6734 G-A & $\mathrm{G}$ & A & Yes \\
\hline & $7028 \mathrm{C}-\mathrm{T}$ & $\mathrm{C}$ & $\mathrm{T}$ & Yes \\
\hline & $7418 \mathrm{C}-\mathrm{T}$ & $\mathrm{C}$ & $\mathrm{T}$ & Yes \\
\hline MT-ATP8 & 8414 C-T( Leu17Phe) & $\mathrm{C}$ & $\mathrm{T}$ & Yes \\
\hline$M T-A T P 6$ & 8701 A-G(Thr59Ala) & A & G & Yes \\
\hline & $8860 \mathrm{~A}-\mathrm{G}$ & A & G & Yes \\
\hline$M T-C O X 3$ & $9540 \mathrm{~T}-\mathrm{C}$ & $\mathrm{T}$ & C & Yes \\
\hline & 9856T-C(Ile217Thr) & $\mathrm{T}$ & C & Yes \\
\hline$M T-T G$ & $10029 A-G$ & A & $\mathrm{G}$ & No \\
\hline$M T-N D 3$ & 10398A-G(Thr114Ala) & A & $\mathrm{G}$ & Yes \\
\hline & $10400 \mathrm{C}-\mathrm{T}$ & $\mathrm{C}$ & $\mathrm{T}$ & Yes \\
\hline$M T-N D 4$ & $11719 \mathrm{G}-\mathrm{A}$ & G & $\mathrm{A}$ & Yes \\
\hline$M T-N D 5$ & $12705 \mathrm{C}-\mathrm{T}$ & $\mathrm{C}$ & $\mathrm{T}$ & Yes \\
\hline$M T-N D 6$ & $14668 \mathrm{C}-\mathrm{T}$ & $\mathrm{C}$ & $\mathrm{T}$ & Yes \\
\hline$M T-C Y T B$ & 14766 C-T( Thr7Ile) & $\mathrm{C}$ & $\mathrm{T}$ & Yes \\
\hline & $14783 \mathrm{~T}-\mathrm{C}$ & $\mathrm{T}$ & C & Yes \\
\hline & $15043 \mathrm{G}-\mathrm{A}$ & G & $\mathrm{A}$ & Yes \\
\hline & $15301 \mathrm{G}-\mathrm{A}$ & G & $\mathrm{A}$ & Yes \\
\hline & 15326A-G( Thr194Ala) & $\mathrm{A}$ & $\mathrm{G}$ & Yes \\
\hline
\end{tabular}

Table 3. Alignment of the MT-TG gene from 17 different species. Position 42 is the location of the m.10029A>G mutation. 


\begin{tabular}{|c|c|c|c|c|c|c|}
\hline$\overline{\text { rganism }}$ & $\begin{array}{lll}\text { Acc-stem } & \begin{array}{l}\text { D- } \\
\text { stem }\end{array} & \text { D-loop }\end{array}$ & $\begin{array}{ll}\begin{array}{l}\mathrm{D}- \\
\text { stem }\end{array} & \text { Ac- } \\
\text { stem }\end{array}$ & $\begin{array}{l}\text { Anticd- } \\
\text { loop }\end{array}$ & $\begin{array}{l}\text { V- } \\
\text { region }\end{array}$ & & \\
\hline & 810 & & & $44 \quad 49$ & 61 & 66 \\
\hline ebus & ATTCTCT TA GTAT AAACA & GTACA ATTGA & СТТССАA TTAAT & Г AGGC CTTGA TAAAC & CCAAG & G AGAGAAT A \\
\hline lobus & ATTCTTT TA GTAT AGCCA & GTACA GCTG & А СТТССАА ТСАAС & CTAGC TCCGA TCAACAC & CTCGGA & A AAAGAAT A \\
\hline orilla gorilla & ACTCTTT TA GTAT AATTA & GTACC GTTAA & А СТТССАА TТАAC & CAGT TTTGG TAGTAC & CCAAA & A AAAGAGT A \\
\hline omo sapiens & ACTCTTT TA GTAT AAATA & GTACC GTTAA & А СТТССАА ТТААС & CTAGT TTTGA CAACAT & TCAAA & A AAAGAGT A \\
\hline ylobates lar & АСТСТTT TA GTAT AAACA & GTACT GTTAA & А СТТССАА ТТААС & CAGC TTCGA TAACGC & TCGAA & A AAAGAGT A \\
\hline emur catta & ATTCTTT TA GTAT CGACCCA & ATACA ATTGA & А СТТССААТТАAТ & Г TAAC TTCGG TGAAAA & CCGGA & AAAAGAAT A \\
\hline $\begin{array}{l}\text { lacaca } \\
\text { ulatta }\end{array}$ & ACTCTTT TA GTAT AACAA & GTACA ATTGA & А СТТССАА TCAA] & Г CAGT TTTGA CAACAT & TCAAA & A AAAGAGT A \\
\hline $\begin{array}{l}\text { lacaca } \\
\text { rlvanus }\end{array}$ & ACTCTTT TA GTAT AACCA & GTACA ATTGA & А СТТССАА ТСААТ & Г CAGT TTTGA CAACAT & TCAAA & A AAAGAGT A \\
\hline $\begin{array}{l}\text { ycticebus } \\
\text { jucang }\end{array}$ & GCTCTTTTA GTACAACTA & GTACA ATTGA & А СТТССАA TCAA] & Г AGGA TTTGG TAAATA & А CCAAA & A AGAGAGCA \\
\hline an paniscus & ACTCTTT TA GTAT AAGCA & GTACC GTTAA & А СТТССАА ТТААС & CTAGT TTTGA CAACAT & TCAAA & A AAAGAGT A \\
\hline $\begin{array}{l}\text { an } \\
\text { oglodytes }\end{array}$ & ACTCTTT TA GTAT AAGTA & GTACC GTTAA & А СТТССАА TТАAС & CTAGT TTTGA CAACAT & TCAAA & A AAAGAGT A \\
\hline $\begin{array}{l}\text { apio } \\
\text { amadryas }\end{array}$ & ACTCTTT TA GTAT AATTA & GTACA ATTGA & А СТТССАА TCAAТ & Г CAGC TTTGA CAATAT & TCAAA & A AAAGAGT A \\
\hline $\begin{array}{l}\text { ongo } \\
\text { ygmaeus }\end{array}$ & ACTCTTT TA GTAT AAGCA & GTACC GTTAA & А СТТССАА ТТААС & CAGT TTTGA CAACAC & TCAAA & A AAAGAGT A \\
\hline $\begin{array}{l}\text { ongo } \\
\text { ygmaeus } \\
\text { jelii }\end{array}$ & ACTCTTT TA GTAT AAACA & GTACC GTTAA & А СТТССАА ТТААС & TAGT TTTGA CAACGC & CCAAA & A AAAGAGT A \\
\hline $\begin{array}{l}\text { arsius } \\
\text { ancanus }\end{array}$ & GTTCCTTTA GTAT CAATTA & GTACA ATTGA & А СТТССАА ТСААТ & ГTAGC CCTAG TACAATT & Г CTAGG & G AAGGAAC A \\
\hline $\begin{array}{l}\text { rachypithecus } \\
\text { oscurus }\end{array}$ & SATTCTTT TA GTAT AACTA & GTACA & A CTTCCAA TTAGC & CTAGT TTCGA CAACAT & TCGAA & A AAAGAAT A \\
\hline
\end{tabular}

\section{Figures}




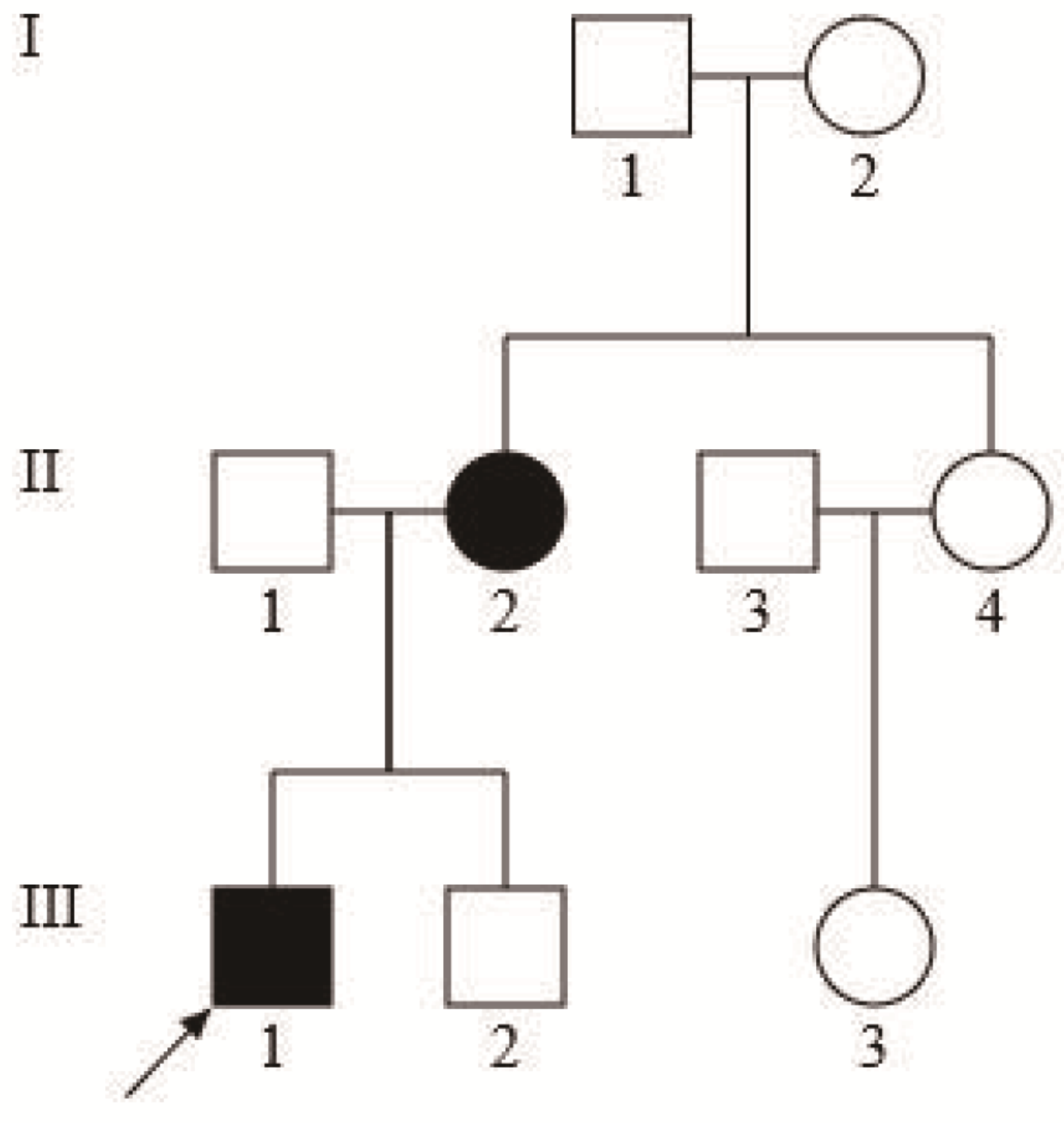

Figure 1

Obesity pedigree. Dark symbols indicate obese individuals. 
$\begin{array}{ccccccccccccc} & C & A & \text { T } & \text { T } & \text { A } & \stackrel{G}{\Downarrow} & \text { C } & \text { T } & \text { A } & \text { G } & \text { T } & \text { T }\end{array}$
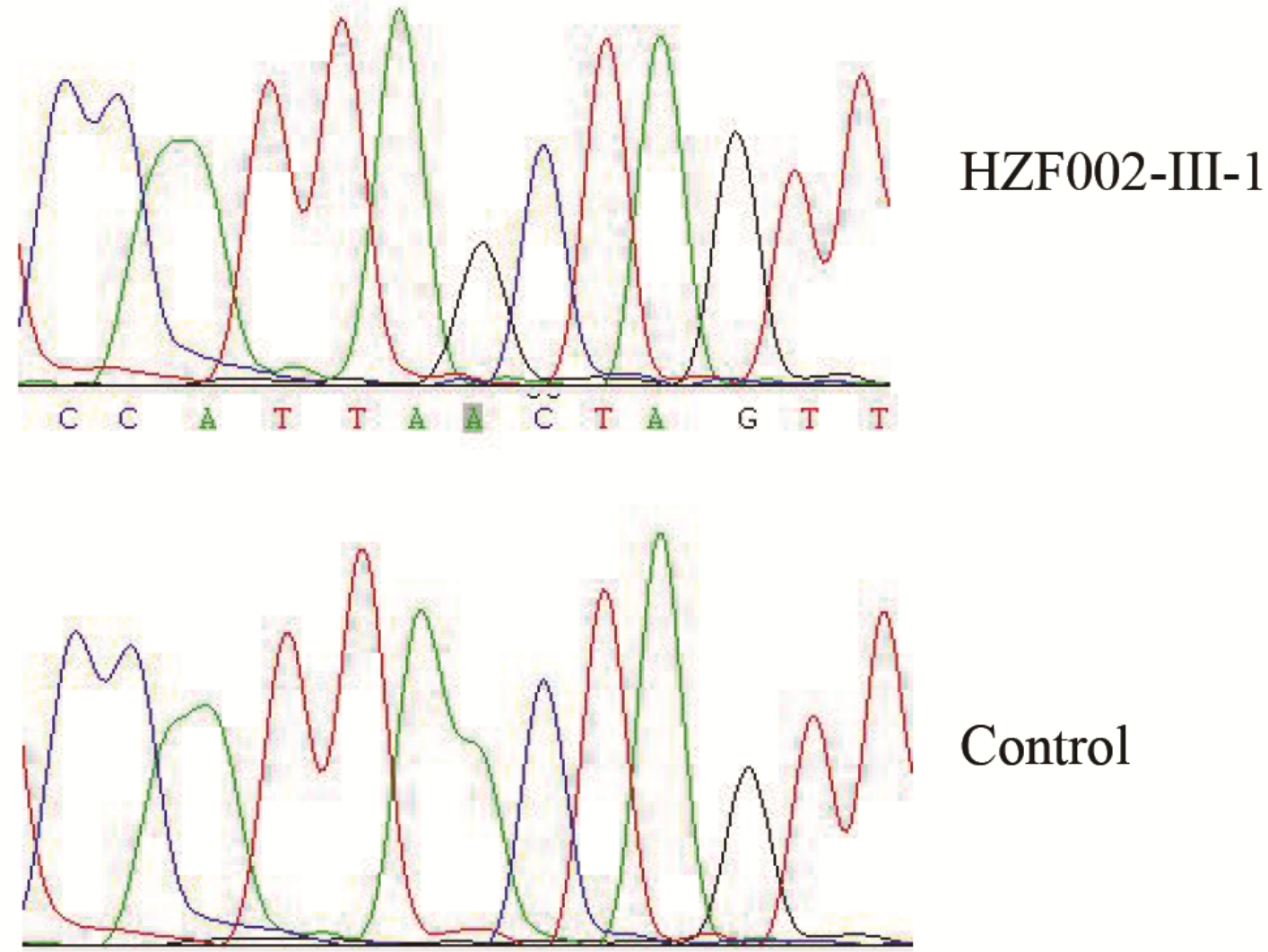

Figure 2

Detection of the tRNA $10029 \mathrm{~A}>\mathrm{G}$. Shown are tRNA sequence chromatograms from proband and a control individuals, with an arrow marking the site of the identified mutation. 
A

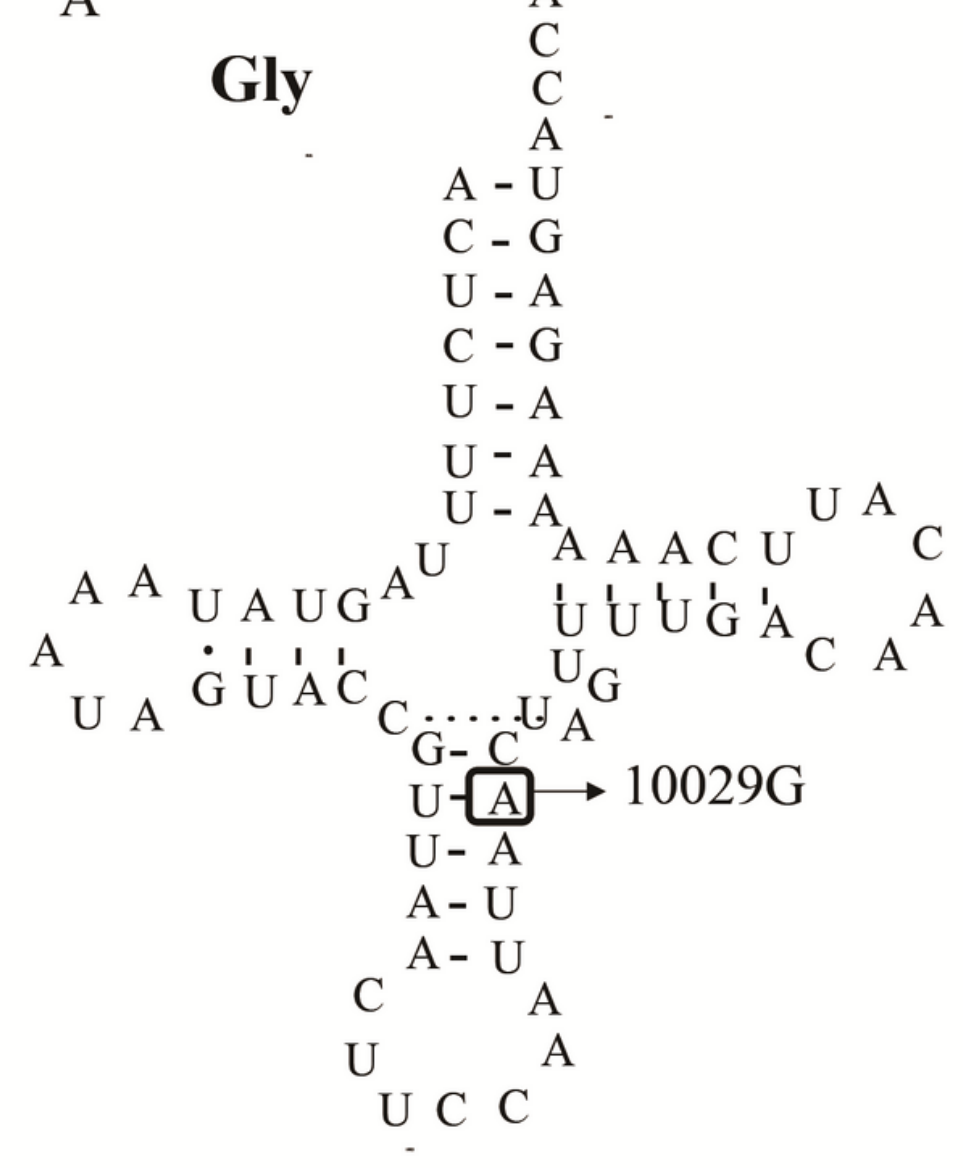

$\mathrm{B}$

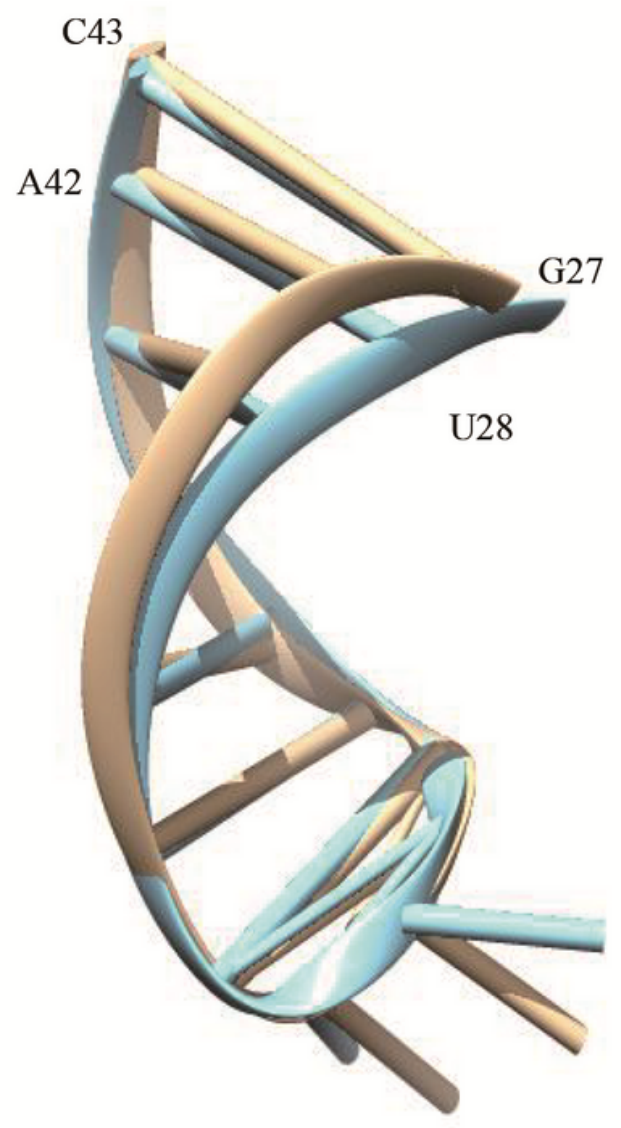

Figure 3

Mitochondrial tRNAGly structure (A) Normally the tRNAGly has a clover-like structure, with the site of the identified mutation marked by an arrow. (B) The simulated tertiary structure of the wild-type and mutated anticodon stem loop of this tRNA is shown (brown and blue, respectively). 
A

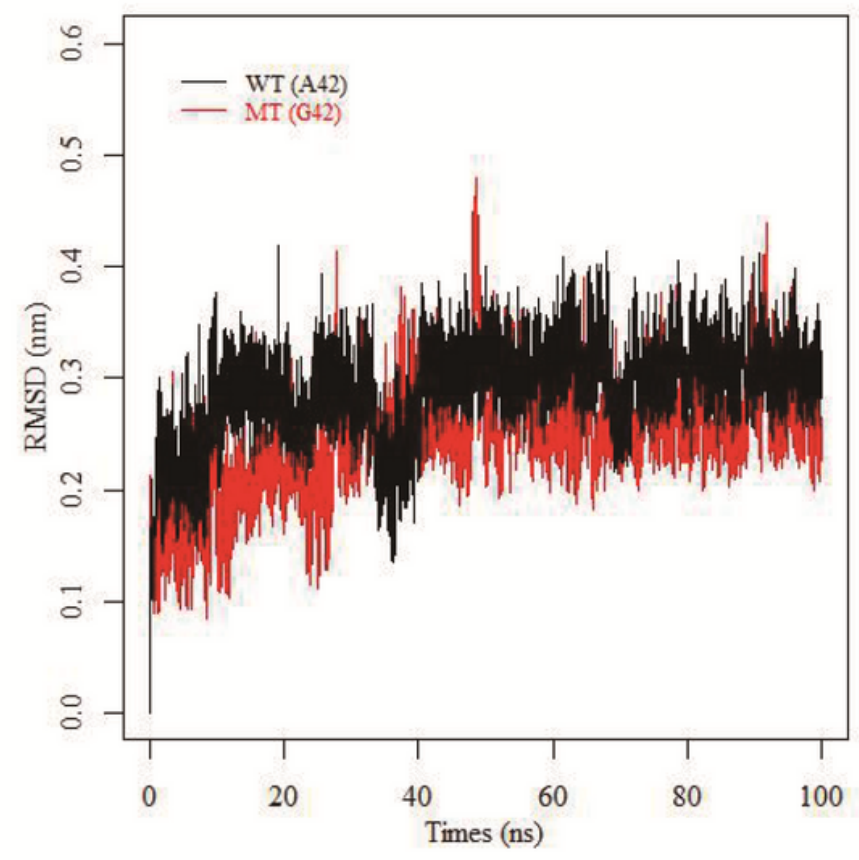

$\mathrm{B}$

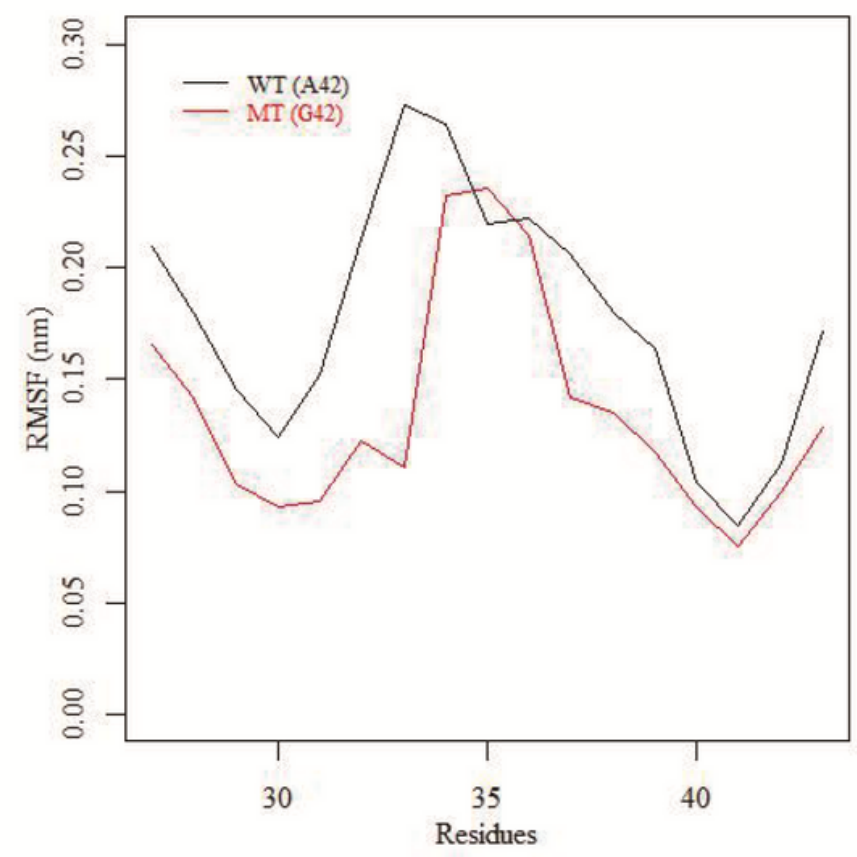

Figure 4

MD simulations of the effects of tRNAGly mutation on the anticodon stem loop. (A) Root mean square deviation (RMSD) values over time for the C口ロatoms are shown for wild type and mutant tRNAGly (black and red, respectively). (B) Backbone atoms of the anticodon stem loop of this tRNA were used to generate RMSF curves for the wild-type and mutant isoforms (black and red, respectively). 